\title{
Realitas Phone Snubbing pada Pergaulan Remaja
}

\section{Reality of Phone Snubbing in Teenager's Relations}

\author{
Dina Alamianti ${ }^{1}$, Rannie Dyah K Rachaju ${ }^{2}$ \\ ${ }^{1,2}$ Universitas Langlangbuana \\ J1. Karapitan No.116 Bandung, Indonesia \\ Email: 1nadien5@gmail.com
}

Received : December 12, 2020 ; Revised: June 10, 2021; Accepted: August 13, 2021

\begin{abstract}
Excessive use of gadgets can lead to phone snubbing behaviour, in this case, teenagers become indifferent to their environment and more focus on playing with their gadgets. The reality of phone snubbing (phubbing) can cause communication barriers such as distortion of messages and cause interpersonal relationships to become disrupted. This research aimed to (1) find out the role of communication actors in phone snubbing reality specifically in adolescent relationships' framework, (2) verbal and nonverbal messages in the reality of phone snubbing, and (3) the meaning of phone snubbing for adolescents. The method used in this research is qualitative, with data collection techniques through in-depth interviews, observations, and documentation. Informants of this research are Bandung's high school students who actively use their gadget. This research concluded that there was a title role in the interaction process of phone snubbing reality, individuals became the committers of communication known as phubber, that is an affected person phubbing, and phubbed as phubbing actors. Verbal messages occur in concurrence with nonverbal messages in the interaction of high school teenager's communication in the form of school chats, gossip, and funny stories accompanied by nonverbal indicated from the closeness of their friendships, there is a ritual touching base message, such as patting the friends' shoulders and the friendship affectionate display. Phubbing behaviour is felt more obvious when they engaged in family's interaction. Phubbing is defined as unlikable behaviour and can interfere with friendships.
\end{abstract}

Keywords: Gadget; Interpersonal Communication; Phone Snubbing; Teenager

\begin{abstract}
Abstrak
Penggunaan gawai yang berlebihan pada remaja dapat menimbulkan perilaku phone snubbing, yaitu kondisi dimana remaja menjadi acuh terhadap lingkungannya dan lebih berfokus bermain dengan gawainya. Realitas phone snubbing (phubbing) dapat menimbulkan hambatan komunikasi seperti distorsi pesan dan mngakibatkan hubungan interpersonal menjadi terganggu. Penelitian ini bertujuan untuk mengetahui peran pelaku komunikasi dalam realitas phone snubbing pada pergaulan remaja, pesan verbal dan nonverbal dalam realitas phone snubbing, serta makna phone snubbing bagi remaja. Metode yang digunakan adalah kualitatif dengan teknik pengumpulan data melalui wawancara mendalam, observasi, dan dokumentasi. Informan penelitian ini adalah siswa Sekolah Menengah Atas (SMA) yang aktif menggunakan gawainya di Kota Bandung. Hasil penelitian menunjukkan bahwa terjadi pengambilan peran pada proses interaksi dalam realitas phone snubbing dimana individu menjadi pelaku phubber yaitu sseorang
\end{abstract}


terdampak phubbing dan phubbed sebagai pelaku phubbing. Pesan verbal terjadi bersamaan dengan pesan nonverbal pada interaksi komunikasi remaja SMA berupa obrolan sekolah, gosip, dan cerita lucu. Pesan non verbal ditunjukkan dengan hubungan pertemanan yang akrab misalnya penyampaian pesan sentuhan ritual yaitu menepuk pundak teman serta adanya affect display. Perilaku phubbing lebih dirasakan dalam konteks interaksi komunikasi pada keluarga. Phubbing dimaknai sebagai perilaku yang tidak disukai dan dapat mengganggu hubungan pertemanan.

Kata Kunci: Gawai; Komunikasi Interpersonal; Phone Snubbing; Remaja

\section{Pendahuluan}

Penggunaan gawai yang berlebihan dapat memberikan dampak negatif pada perilaku remaja. Durasi penggunaan gawai di kalangan remaja yang rata-rata adalah di atas lima jam per hari sudah termasuk pada potensi kecanduan. Remaja saat ini merupakan generasi millenial yang hampir tidak bisa lepas dari gawainya. Remaja menggunakan gawai seperti telepon genggam untuk berkomunikasi dan bermain internet untuk hiburan dan mengerjakan tugas sekolah. Gawai menjadi sebuah kebutuhan primer yang harus ada dalam genggaman. Remaja seperti siswa Sekolah Menengah Atas (SMA) dapat dikategorikan sebagai remaja yang aktif dalam menggunakan gawainya merupakan kelompok yang paling rentan terhadap perilaku phone snubbing ketika berinteraksi dengan lingkungannya.

Perilaku remaja yang tak acuh ketika sedang berada dalam sebuah lingkungan dan lebih memilih berfokus pada gawainya membuat komunikasi seringkali tidak efektif.

Ketika berkomunikasi tatap muka terjadi proses interaksi di antara dua orang atau lebih, interaksi yang efektif adalah yang bersifat dua arah, namun bila pesan yang disampaikan dalam berinteraksi terganggu maka interaksi menjadi bersifat searah dan terdapat hambatan komunikasi, baik secara verbal maupun non verbal. Padahal bila dilihat dari perspektif komunikasi, salah satu indikator suatu komunikasi dikatakan efektif dikarenakan adanya kesamaan pemahaman antara pengirim dan penerima pesan (Devito 2015).

Penelitian tentang phubbing belum banyak dilakukan mengingat phubbing adalah fenomena baru yang berkembang pada masyarakat saat ini. Penelitian phubbing yang dilakukan oleh (Hanika 2015) dengan judul "Fenomena Phubbing di Era Millenia”: Ketergantungan seseorang pada smartphone terhadap lingkungannya" menunjukan hasil bahwa sekalipun responden melakukan phubbing ternyata mereka juga merasa terganggu jika orang lain melakukan phone snubbing. Penelitian yang dilakukan oleh (Youarti and Hidayah 2018) mengenai "Perilaku Phubbing sebagai Karakter Remaja Generasi $Z$ " mengemukakan bahwa tawaran modernitas yang diberikan ternyata membawa dampak negatif yang 
cukup memprihatinkan. Salah satunya adalah dengan kemunculan istilah phubbing sebagai indikasi kecanduan generasi $\mathrm{Z}$ terhadap smartphone menjadikan seorang remaja rela menyakiti orang-orang yang ada disekitarnya dengan bersikap acuh dan lebih berfokus pada smartphonenya. Dari sisi bimbingan dan konseling, pendekatan CBT merupakan terapi yang sesuai dan dapat digunakan oleh seorang konselor untuk mengatasi perilaku phubbing.

Penelitian lainnya dilakukan oleh oleh (Normawati, Maryam and Priliantini 2018) yang berjudul Pengaruh Kampanye "Let's Disconnect To Connect" Terhadap Sikap Anti Phubbing; Survei pada followers official account LINE Starbucks Indonesia mengemukakan bahwa kampanye Let's Disconnect to Connect mampu mempengaruhi terciptanya sikap anti phubbing sebanyak $65,2 \%$. Isi dan struktur pesan yang disajikan pada broadcast official account LINE dianggap menarik dan informatif, sehingga mampu meberikan awareness, knowledge dan motivasi bagi followers official account LINE Starbucks Indonesia untuk melakukan sikap anti-phubbing yang ditunjukkan dengan kesediaannya meletakkan smartphone-nya. The Effect of Phubbing on Social Interaction oleh Varoth C. \& Karen M.Douglas melakukan social experiment dengan mengukur tingkat perilaku phubbing yang mempengaruhi komunikasi dan hubungan dengan pasangannya (Chotpitayasunondh and Douglas 2018).

\begin{abstract}
Penelitian lainnya yang berjudul "Mengenalkan phubbing kepada Remaja SMA melalui Webseries" dilakukan oleh Riko Taufik Akbar, et al., menjelaskan bahwa pada dasarnya Indonesia masih belum memiliki kampanye yang berkaitan dengan phubbing padahal dampaknya negatif (Akbar, Dewanto and Wibowo 2003). Perilaku phone snubbing apabila dibiarkan dan berlanjut dapat berdampak negatif seperti merusak kehidupan sosial seseorang, individu menjadi lebih individualis, apatis, dan bahkan anti sosial. Berdasarkan dari pemaparan latar belakang maka tujuan dari penelitian ini adalah untuk memperoleh gambaran lengkap tentang peran dari pelaku komunikasi dalam realitas phone snubbing, pesan verbal dan nonverbal dalam realitas phone snubbing, serta makna phone snubbing bagi remaja.
\end{abstract}

\section{Kerangka Teori}

Realitas phubbing pada pergaulan remaja dapat mengganggu hubungan interpersonal yang didalamnya melibatkan konteks komunikasi antarpribadi. Komunikasi antarpribadi merupakan komunikasi yang melibatkan dua orang atau lebih. Komunikasi yang didalamnya terdapat unsur keakraban dan dapat saling mempengaruhi interaksi yang terjadi, pesan yang disampaikan dalam komunikasi adalah pesan verbal dan nonverbal. (Mubarok and Andjani 2014, 75).

Pesan-pesan dalam komunikasi antarpribadi yaitu melalui pesan verbal dan nonverbal. Pesan verbal adalah semua jenis simbol yang menggunakan satu kata atau lebih. 
Bahasa dapat dianggap sebagai sistem kode verbal. Bahasa verbal adalah sarana yang utama untuk menyatakan pikiran, perasaan dan maksud seseorang. Pesan nonverbal adalah semua isyarat yang bukan kata-kata, misal isyarat fisik, ekspresi wajah. Nonverbal sendiri diklasifikasinya menjadi tiga bagian utama, yakni bahasa tanda (sign language), bahasa tindakan (action language), dan bahasa objek (object language) (Mulyana 2017)

Komunikasi interpersonal tidak hanya membahas mengenai pelaku komunikasi dan pesannya namun juga terkait dengan pengembangan sebuah hubungan. Pengembangan hubungan interpersonal merupakan faktor penting dalam komunikasi interpersonal. Terdapat beberapa tahapan pengembangan diantaranya adalah tahap kontak, tahap keterlibatan, tahap keakraban, tahap kerusakan dan tahap pemutusan yang menggambarkan hubungan apa adanya. Hubungan interpersonal dapat dilihat juga dari kedalaman dan keluasan sebuah hubungan yang terkait dengan banyaknya topik yang dibicarakan dan derajat kepersonalan dalam topik yang dibicarakan tersebut (Devito 2015)

Penelitian ini adalah untuk mendeskripsikan realitas phone snubbing pada pergaulan remaja yakni proses pertukaran pesan verbal dan nonverbal yang terjadi ketika berkomunikasi serta menciptakan makna dengan menginterpretasikan pesan yang disampaikan ketika dihadapkan pada komunikasi tatap muka diantara dua orang atau lebih dan adanya kecenderungan terjadi perilaku phone snubbing. Untuk memahami peran pelaku komunikasi, setiap pelaku komunikasi saling mempengaruhi dan memiliki perannya masing-masing ketika berinteraksi dengan orang lain.

Teori interaksi simbolik menjadi teori yang digunakan untuk mengeksplorasi hubungan antara diri dan masyarakat pada lingkungannya. Interaksi simbolik menyatakan bahwa orang bertindak terhadap orang lain atau suatu peristiwa berdasarkan makna yang mereka berikan kepada orang lain. Teori interaksi simbolik menekankan pada hubungan antara simbol dan interaksi. Tema pokok dari interaksi simbolik yaitu pentingnya makna bagi perilaku manusia, pentingnya konsep mengenai diri, dan hubungan antara individu dengan masyarakat. Menurut George Herbert Mead, diri berkembang melalui sebuah jenis pengambilan peran yang khusus maksudnya adalah membayangkan bagaimana kita dilihat oleh orang lain. (Turner 2009).

Phone Snubbing (phubbing) merupakan kosa kata baru yang dapat diartikan sebagai tindakan acuh seseorang dalam lingkungan karena lebih fokus pada gawai daripada berinteraksi atau melakukan percakapan. Realitas phubbing muncul bersamaan dengan semakin banyaknya smartphone atau telepon genggam yang ada sebagai akibat dari semakin masifnya perkembangan teknologi komunikasi di era digital saat ini. Dampak dari teknologi komunikasi, dengan kehadiran smartphone, internet, dan gawai lainnya berpengaruh pada kehidupan sosial di masyarakat. Seperti adanya perubahan cara berkomunikasi di masyarakat, dengan hadirnya teknologi 
komunikasi maka memudahkan manusia untuk beraktivitas dalam kehidupan sehari-hari. Namun dibalik dampak positif terdapat dampak negatif yang mana masyarakat menjadi adiksi terhadap smartphone-nya. Adiksi karena adanya aktivitas neurotransmitter yaitu terjadi proses pembiasaan yang dilakukan ketika mengakses gawainya, sehingga adanya kepuasan yang dirasakan dimana pada akhirnya menimbulkan rasa ketagihan, ada perasaan ingin selalu terpenuhi, misalnya ketertarikan terhadap sebuah aplikasi pada gawai, yang membuat orang ingin selalu mengakses aplikasi tersebut pada jam-jam tertentu dan hal ini dilakukan secara terus menerus. Dalam konteks psikologi komunikasi hal ini erat kaitannya dengan classical conditioning, yang mana terjadi proses pembelajaran dan menjadi kebiasaan (Rakhmat 2011).

Frekuensi yang dihabiskan dalam menggunakan gawainya semakin meningkat karena ada kesulitan pada individu untuk berhenti memenuhi rasa penasaran pada individu dan tidak pernah berhenti bahkan cenderung meningkat sehingga menjadi motivasi yang menyimpang. Adiksi membuat seseorang semakin tergantung dengan gawainya dan sulit mengontrol keinginannya untuk mengakses aplikasi tertentu bahkan pada tahap tertentu bisa menciptakan memori refleks baru pada individunya. Ketergantungan pada smartphone yang sangat tinggi menyebabkan seseorang menjadi gelisah, cemas, dan tidak bisa tenang jika smartphone-nya ketinggalan di rumah misalnya, ini lah yang disebut gejala nomophobia (no mobile phone phobia) (Nurudin 2017).

Manusia di era digital semakin akrab dengan teknologi, mereka yang seharusnya akrab dengan manusia dan berinteraksi tatap muka malah justru lebih banyak menghabiskan waktunya dengan gawai sebagai produk dari teknologi komunikasi. Hal ini memunculkan kekhawatiran karena manusia dapat menjadi tidak peka terhadap lingkungannya. Realitas yang ada saat ini, walaupun banyak terhubung di dunia maya, namun di dunia nyata tidak terhubung dalam interaksi sosial hal ini menimbulkan realitas baru seperti phubbing. Munculnya phubbing disertai dengan fenomena "stop phubbing" untuk menumbuhkan kesadaran tentang phubbing di masyarakat. Upaya yang dapat dilakukan untuk mengatasi phubbing ada 2 bentuk, yakni yang bersifat kuratif dan preventif. Langkah penanganan secaara kuratif ketika memang phubbing sudah menjadi adiksi, sehingga memerlukan terapi secara psikologis. Langkah preventif dapat dilakukan dengan cara memberikan pengalihan yang lebih produktif, misalnya dengan mengarahkan remaja untuk membuat konten sehingga ada karya yang dihasikan dan tidak hanya sebagai pengguna pasif dalam mengakses gawainya atau sebagai penikmat. Proses pengalihan dengan mengarahkan pada pembuatan konten akan mendorong remaja untuk membaca, menganalisis, dan berpikir untuk berkreasi dengan dukungan lingkungan yang suportif.

Realitas phubbing dapat mengganggu komunikasi interpersonal yang mana ketika 
seorang individu lebih disibukkan dengan smartphone-nya daripada berinteraksi dengan yang lain, maka hal ini dapat menimbulkan distorsi yang mengganggu pengoptimalan pesan yang disampaikan. (Hanika 2015)

\section{Metode Penelitian}

Desain penelitian yang digunakan dalam penelitian ini adalah penelitian kualitatif. Penelitian kualitatif dapat diartikan sebagai proses investigasi yang didalamnya peneliti secara perlahan memaknai suatu fenomena sosial dengan membedakan, membandingkan, menggandakan, mengatalogkan dan mengklasifikasikan objek penelitian. (Cresswell 2016)

Pengumpulan data berdasarkan penelitian kualitatif yaitu dengan wawancara mendalam (in depth interview), observasi, dan dokumentasi. Pengumpulan data dikumpulkan menjadi data primer dan data sekunder. Data primer diperoleh dari observasi dan wawancara, data sekunder diperoleh melalui dokumentasi untuk keperluan analisis dalam penelitian. Untuk menyajikan data agar mudah dipahami, maka langkah-langkah analisis data yang digunakan dalam penelitian adalah Analysis Interactive Model dari Miles dan Huberman, yang membagi langkah-langkah dalam kegiatan analisis data dengan beberapa bagian yaitu pengumpulan data (data collection), reduksi data (data reduction), dan penyajian data (data display). (Miles, Huberman and Saldana 2014).

Informan dalam penelitian ini adalah remaja SMA Taruna Bakti dengan usia 16-18 tahun yang aktif dalam menggunakan smartphonenya di kota Bandung yang berjumlah 4 (empat) orang informan serta 1 (satu) guru Bimbingan Konseling (BK) sebagai informan yang mampu menjelaskan interaksi sosial remaja di sekolah.

\section{Hasil Penelitian dan Pembahasan \\ Berdasarkan dari temuan hasil penelitian melalui observasi, wawancara mendalam dan dokumentasi kemudian dilakukan analisis data, maka pembahasan diuraikan dan dirinci serta disajikan berdasarkan rumusan masalah dan tujuan penelitian sebagai berikut :}

\section{Peran Pelaku Komunikasi realitas} phubbing pada remaja.

Peran manusia sebagai pelaku komunikasi pada hubungan antar pribadi menjadi penting, bila dikaitkan dengan realitas phone snubbing maka dapat mengganggu proses komunikasi yang terjadi dengan lingkungannya. Phubbing dapat terjadi dikarenakan terlalu berfokus bermain atau menggunakan gawainya, hal ini terkait dengan intensitas waktu yang digunakan dalam menggunakan gawai yang dapat mengarah kepada kecanduan gawai dan mengakibatkan ketidakpeduliannya terhadap lingkungan sekitar. Frekuensi atau banyaknya waktu yang dihabiskan ketika menggunakan handphone pada remaja, dijelaskan oleh informan kebanyakan menghabiskan waktu dengan gawainya kurang lebih tiga jam bahkan hingga empat jam yang mana penggunaan waktu tersebut diatas waktu rata-rata menggunakan handphone dan 
berpotensi pada perilaku kecanduan. Ukuran normal dalam mengakses gawai adalah kurang lebih 2 jam, bila mengaksesnya lebih dari normal dan dilakukan secara terus menerus selama 6 bulan berturut-turut maka ada indikasi mengarah pada adiksi.

Adiksi atau kecanduan internet menjadi jenis perilaku, yang pada akhirnya mengganggu interaksi dengan lingkungannya. Seseorang tidak dapat mengontrol dorongannya dalam menggunakan gawainya sehingga tidak mengenal waktu dan dengan siapa dirinya berinteraks. Waktu yang digunakan dengan gawainya pada remaja adalah untuk belajar, bermain games dan berkomunikasi menggunakan media sosial seperti whatsapp, instagram dan menonton youtube. Akhirnya hal ini dapat berdampak pada proses interaksi yang terjadi pada lingkungannya. Ketika proses interaksi, terkadang seseorang dapat mengambil peran sebagai pelaku phubbing atau orang yang terdampak phubbing, terdapat beberapa hal yang dapat dijadikan indikasi peranan pelaku komunikasi yang diambil selama proses interaksi bahwa phubbing itu bermain handphone saat mengobrol tatap muka dan phubbing itu berfokus pada handphone saat berkomunikasi dengan orang lain.

Pengambilan peran (role taking) dapat terjadi ketika berinteraksi dimana informan pernah melakukan hal yang sama atau sibuk dengan handphone-nya dikarenakan faktor situasi yang terasa canggung. Informan menyebutkan dirinya pernah lebih memilih bermain handphone dikarenakan suasananya yang dikatakan awkward dan bahkan pernah berperilaku phubbing ketika berinteraksi dikarenakan merasa teman berbicaranya membosankan, atau merasa tidak diharapkan dalam pembicaraan. Bila dikaitkan dengan realitas phubbing, manusia dapat menjadi pelaku phubbing atau disebut phubber dan yang terdampak phubbing atau phubbed.

Seperti yang diungkapkan oleh DeVito, bahwa komunikasi merupakan proses dua arah. Setiap orang harus berfungsi sebagai sumber dan sebagai penerima. Setiap orang mempunyai kesempatan untuk berfungsi sebagai subjek (Devito 2015)

Pesan verbal dan non verbal dalam realitas phubbing.

Pesan verbal dalam realitas phubbing berlangsung melalui percakapan yang dilakukan diantara dua orang atau lebih yang terlibat dalam interaksi. Bentuk percakapan yang terjadi pada remaja SMA seperti cerita lucu, laki-laki atau berita update seperti gosip yang mana dalam interaksi sehari-hari tidak bisa lepas dari gosip. Pesan verbal yang dilakukan oleh informan melibatkan kata "kita" dimana hal ini menandakan ungkapan kebersamaan dan menunjukkan kedekatan.

Menurut DeVito, komunikasi interpersonal seseorang dapat mengikatkan diri lebih jauh dengan orang lain dengan membina hubungan yang primer (Devito 2015, 256).

Menurut informan, dalam melakukan proses interaksi yang berlangsung antar teman tidak pernah lepas dari gawai yang digunakan, misalnya memperbincangkan video tertentu. 
Maka secara langsung gawai menjadi bagian yang tidak bisa dipisahkan dalam kehidupan sehari-hari. Komunikasi yang terjadi dalam realitas phubbing menyebabkan pengirim pesan merasa tidak suka, tidak dihargai, kesal, dan menjadi malas untuk berbicara.

Dalam membangun hubungan interpersonal, daya tarik antarpribadi menjadi penting, misalnya: rasa menghargai orang lain. Pada realitas phubbing, seringkali komunikator akan bereaksi secara tiba-tiba dan pesan verbal yang muncul adalah ungkapan kekesalan karena keinginan untuk dihargai lawan bicara tidak terpenuhi dan ungkapan marah dengan cara menegur karena terjadi hambatan komunikasi disebabkan gawai. Sibuk dengan diri sendiri menjadi penghambat paling serius dan merusak proses mendengarkan yang efektif. Dalam proses mendengarkan terjadi proses aktif menerima rangsangan (stimulus) dan diperlukan komitmen dalam mendengarkan.

Pengembangan hubungan interpersonal dapat terjadi dalam interaksi ketika komunikator dihadapkan pada komunikan yang dalam hal ini adalah remaja SMA dan teman sekelas. Dalam prosesnya terdapat tahap keakraban dan dalam interaksi ada tahap kontak serta keterlibatan. Apabila merasa diacuhkan oleh temannya, respons yang diberikan beragam yang dapat diungkapkan dalam kalimat agar ada ketertarikan untuk kembali berinteraksi. Terdapat beberapa kalimat yang diungkapkan informan penelitian, diantaranya: "ih mau cerita!" "aku udah cerita belum?", "kemaren ya.., woy si ini teh....”,"eh tau gak..”. Kalimat tersebut dapat menjadi contoh pernyataan dalam tahap keterlibatan dalam pembicaraan yang dapat dimaknai bahwa terdapat pernyataan langsung yang mengungkapkan keinginan untuk melibatkan diri diantara remaja SMA.

Hubungan interpersonal yang baik didasarkan pada komunikasi yang baik pula. Maka salah satu unsur penting dalam komunikasi yaitu pesan haruslah dikemas dengan baik dan efektif. Pesan yang efektif adalah pesan yang disampaikan dapat jelas diterima oleh komunikan. Apabila terjadi hambatan komunikasi, misalnya satu diantara lawan bicara berfokus pada gawainya maka pesan akan terdistorsi, pengiriman pesan menjadi tidak optimal. Miscommunication terjadi satu diantaranya karena keakuratan dan kejelasan pesan yang disampaikan menjadi tidak optimal, karena simbol berubah-ubah, abstrak, ambigu yang mengakibatkan adanya potensi kesalahpahama (Wood 2013). Pesan yang disampaikan menjadi tidak optimal dikarenakan ada jeda ketika berinteraksi, dan respon yang diberikan ketika informan lebih memilih untuk tidak melanjutkan pembicaraan.

Pengembangan hubungan interpersonal di dalam lingkungan sekolah terkait dengan interaksi sosial atau pergaulan remaja adalah ketika remaja lebih terbuka untuk melakukan komunikasi di ruang digital seperti grup whatsapp, line maupun DM instagram. Sekolah dapat memantau interaksi yang terjadi melalui aplikasi media sosial sebagai instrumen tugas 
perkembangan diri $\begin{array}{r}\text { siswa. } \\ \text { Berdasarkan }\end{array}$
perkembangan trumen
sekolah dapat memberikan program
edukasi bila ada kelas yang
bermasalah. Program edukasi
tersebut terkait dengan kurikulum
sekolah mengenai literasi digital.
Hingga saat ini kurikulum terkait
literasi digital yang diberikan
sekolah masih dalam tataran
prosedural.

Pesan nonverbal adalah pesan yang berisi isyarat dan bukan katakata. Secara keseluruhan manusia ketika berinteraksi mengirim pesan nonverbal yang tanpa disadari pesan dapat bermakna bagi orang lain .Pesan nonverbal dalam realitas phone snubbing dapat ditunjukkan ketika berinteraksi seperti ekspresi wajah datar yang dapat dilihat dari lawan bicara yang lebih memilih sibuk dengan gawainya. Wajah dapat mengomunikasikan berminat atau tak berminat pada orang lain atau lingkungan dan wajah mengomunikasikan intensitas keterlibatan dalam situasi dan wajah dapat juga mengomunikasikan adanya pengertian atau kurangnya pengertian (Mubarok and Andjani 2014). Ekspresi wajah datar yang seringkali terdapat dalam realitas phone snubbing menunjukkan bahwa affect display kurangnya minat atau bahkan tidak berminat dalam interaksi yang dilakukan. Serta ekspresi wajah tersenyum yang dapat juga mengomunikasi intensitas keterlibatan pada situasi interaksi yang terjadi. Affect display menunjukkan gerakan muka sehingga dapat mengomunikasikan makna emosional. Pesan gestural seperti gerakan mata lebih banyak memainkan peranannya dalam menimbulkan affect display dalam realitas phone snubbing.

Ketika berinteraksi dalam realitas phubbing, ekspresi wajah dapat terlihat datar dan membosankan dari lawan bicara yang lebih memilih sibuk dengan gawainya. Dukungan dari gerakan mata dapat terjadi pada situasi phubbing, pesan yang dikomunikasikan oleh mata bervariasi bergantung pada durasi, arah, dan kualitas dari perilaku mata. Kontak mata dengan durasi yang lebih singkat, dapat dipahami bahwa orang tersebut tidak berminat, malu, atau sibuk.

Pesan nonverbal dapat dilihat dari interaksi yang dibangun berdasarkan pertemanan yang memiliki faktor kedekatan (proksimitas) dimana perkembangan pertemanan bahkan persahabatan dipengaruhi oleh jarak antara unitunit dimana seseorang tinggal. Pesan proksemik disampaikan melalui pengaturan jarak dan ruang. Pada umumnya mengatur jarak dapat mengungkapkan keakraban dengan orang lain. Ketika berkomunikasi dalam realitas phone snubbing, ruang dan jarak menjadi kondisional. Umumnya, wanita menyentuh dan disentuh lebih banyak daripada pria. Pola sentuhan dapat berbeda dan sangat ditentukan oleh kondisi budaya disekitarnya. Perlakuan terhadap ruang dapat pula dipengaruhi oleh faktor-faktor seperti status, kultur, konteks, jenis kelamin, usia, pokok persoalan serta evaluasi positif atau negatif atas orang lain.

Hubungan interpersonal pada hubungan persahabatan dapat dilihat dari faktor memiliki kesamaan jenis 
kelamin perempuan dengan usia yang hampir sebaya serta berada dalam sekolah yang sama dan memiliki obrolan yang sama sehingga semakin terjalin keakraban dan berpengaruh pada kondisi komunikasi sentuhannya. Kedekatan dengan orang lain dipertegas dengan tahap pengembangan hubungan interpersonal, terdapat pesan sentuhan atau touch secara formal dikenal sebagai haptics (Budyatna and Ganiem 2011). Contohnya adalah sentuhan ritual yang terkadang terpusat pada salam dan perpisahan. Sentuhan ritual juga meliputi pelukan, ciuman atau meletakkan lengan di bahu orang lain. Sentuhan dapat juga dengan mengarahkan atau mengendalikan, sentuhan dapat mengarahkan perilaku, sikap, atau perasaan orang lain.

Pengarahan dapat mengomunikasikan sejumlah pesan misal dalam bentuk perintah seperti "cepat", "kerjakan" atau untuk menarik perhatian, menyentuh orang untuk menarik perhatian seakan-akan mengatakan "lihatlah saya". Seperti ungkapan "touching” dengan menepuk pundak sebagai sentuhan ritual atau sentuhan untuk menarik perhatian. Apabila hubungan berkembang, sentuhan juga akan ikut berkembang.

\section{Makna phubbing bagi remaja.}

Manusia menciptakan simbol dan menggunakannya dalam komunikasi, dan manusia menciptakan makna dan tanggapan kepada simbol-simbol tersebut. Sebagai manusia tidak hanya mampu membuat peristiwa tetapi juga kegunaan dan makna peristiwa tersebut. Realitas phone snubbing (phubbing) dimaknai sebagai perilaku yang tidak disukai dan bila dilakukan secara terus menerus maka dapat mengganggu komunikasi dan proses interaksi yang terjadi dan berakibat pada status hubungan pertemanan. Perilaku phubbing menjadi tidak disukai, dianggap tidak sopan, dan dapat menimbulkan misscommunication, komunikasi dapat terhenti.

Selain di lingkungan pergaulan dengan teman sebaya, ternyata realitas phubbing juga dirasakan informan pada saat berada di lingkungan keluarga. Keluarga memiliki peran penting dalam proses langkah pencegahan phubbing, terutama dalam memberikan pengalihan kegiatan di luar sekolah dalam mengakses gawainya. Informan mengeluhkan sering tidak adanya respon saat berinteraksi di rumah sehingga komunikasi terhenti. Hal ini sejalan dengan phubbing dalam konteks pemrosesan informasi, yaitu terjadi proses atensi yang berlebihan, sehingga dengan penggunaan gawai yang berlebihan menjadi sebuah ketertarikan tersendiri dan dapat mengakibatkan seseorang mengabaikan lingkungannya, hal ini menjadikan tingkah laku phubbing menjadi perilaku yang asosial. Bila dilihat dari, konteks komunikasi interpersonal adalah melibatkan masalah etika.

Komunikasi yang beretika dapat terjadi ketika seseorang dapat menciptakan hubungan yang seimbang serta saling mencerminkan sikap empati. Rusaknya hubungan interpersonal terjadi pada saat komunikator atau komunikan merasa 
terganggu ketika berinteraksi seperti realitas dalam phubbing.

\section{Bagan 1.Hasil Temuan Penelitian}

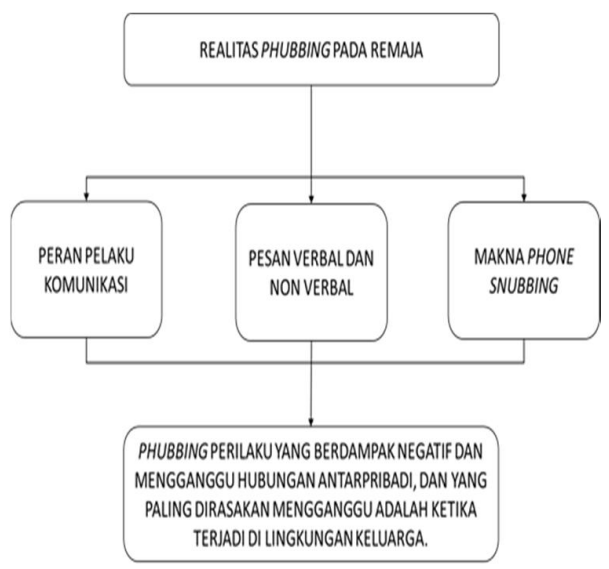

Sumber: Data Penelitian, 2020

\section{Simpulan}

Peran pelaku komunikasi dalam realitas phone snubbing dapat terjadi pada proses interaksi. Istilah phubber merujuk pada peranan seseorang yang melakukan phubbing dan phubbed merupakan pihak yang terdampak dari phubbing. Phubber dan phubbed merupakan role taking yang dilakukan dari individu yang saling berinteraksi. Pesan bahasa verbal dalam realitas phubbing dapat dilihat dari percakapan yang dilakukan oleh remaja yang terlibat dalam interaksi. Bentuk percakapan dapat berupa obrolan sekolah, gosip, laki-laki, dan cerita lucu.

Penggunaan kata "kita" menjadi dominan dalam setiap pesan yang disampaikan dikarenakan hubungan pertemanan yang telah terjalin melibatkan unsur keakraban dan dapat mempengaruhi pesan nonverbal yang disampaikan. Pada penyampaian pesan nonverbal dalam realitas phubbing memunculkan affect display seperti pihak yang terlibat dalam komunikasi kurang berminat dalam terlibat pembicaraan, namun melibatkan komunikasi sentuhan dengan tujuan menarik perhatian lawan bicara.

Makna phone snubbing bagi remaja tindakan yang tidak disukai dan dapat mengganggu hubungan pertemanan yang telah terjalin. Realitas Phubbing dapat mengakibatkan ketidaknyamanan dalam proses komunikasi.

\section{Referensi}

Akbar, Riko Taufik, Inko Sakti Dewanto, and Adrianto Wibowo. "Mengenalkan Phubbing kepada remaja SMA melalui Webseries." Jurnal Rekamakna (ITENAS) -, no. - (2003): KV 402 1-13.

Budyatna, Muhammad, and Leila Mona Ganiem. Teori Komunikasi Antarpribadi. Jakarta: Kencana, 2011.

Chotpitayasunondh, Varoth, and Karen M. Douglas. "The Effects of 'Phubbing' on Social Interaction ." Journal of Applied Social Psychology 48, no. 6 (2018): 304-316.

Cresswell, J. W. Research Design, Pendekatan Metode Kualitatif, Kuantitatif, dan Campuran. Yogyakarta: Pustaka Pelajar, 2016.

Devito, J. A. Komunikasi Antarmanusia. Tangerang: Karisma Publishing Group, 2015.

Hanika, Ita Musfirowati. "Fenomena Phubbing di Era Milenia." Jurnal INTERAKSI IV, no. 1 (2015): 42-51. 
Miles, Matthew B., A. Michael

Huberman, and Johny Saldana. Qualitative Data Analysis. CA-US: SAGE Publication, 2014.

Mubarok, and Made Dwi Andjani. Komunikasi Antarpribadi dalam Masyarakat Majemuk. Jakarta Timur: Dapur Buku, 2014.

Mulyana, D. Ilmu Komunikasi Suatu Pengantar. Bandung: PT Remaja Rosdakarya., 2017.

Normawati, Siti Maryam, and Anjang Priliantini. "Pengaruh Kampanye "Let's Disconnect to Connect" terhadap Sikap Anti Phubbing ." Jurnal Komunikasi, Media dan Informatika VII No. 3, no. 11 (2018): 155-164.

Nurudin. Perkembangan Teknologi Komunikasi. Jakarta: Rajagrafindo Persada., 2017.

Rakhmat, Jalaludin. Psikologi Komunikasi. Bandung: Remaja Rosda Karya, 2011.

Turner, Richard West \& Lynn H. Pengantar Teori Komunikasi: Analisis dan Aplikasi (Terjemahan). Jakarta: Salemba Humanika, 2009.

Wood, Julia T. Komunikasi Interpersonal: Interaksi Keseharian. Jakarta: Salemba Humanika, 2013.

Youarti, Inta Elok, and Nur Hidayah. "Perilaku Phubbing sebagai Karakter Remaja Generasi Z." Jurnal Fokus Konseling IV, no. 1 (2018): 143-152. 